\title{
Spory wokół kształtu niemieckiej radiofonii w okupowanej Polsce
}

\begin{abstract}
Abstrakt: Polityka radiofoniczna III Rzeszy wobec Polski w czasach okupacji stanowi część strategii dyskryminacji i kulturalnej eksterminacji. Ale była też pełna nieoczekiwanych zwrotów wynikających z nieustających sporów wokół jej pryncypiów. Zdumiewa konsekwentna postawa Hansa Franka, który domagał się dla Generalnej Guberni nie tylko odrębnej niemieckojęzycznej radiofonii, ale również szerokiego spektrum audycji w języku polskim. Nie udało mu się do tego przekonać władz w Berlinie.
\end{abstract}

Słow a klu czowe: radiofonia w III Rzeszy, Hans Frank, Joseph Goebbels, Generalna Gubernia, Kraków, Reichs-Rundfunk-Gesellschaft, dyskryminacja kulturalna.

Abstract: The Third Reich's radio policy towards Poland during the occupation was part of the discrimination and cultural extermination strategy. But it was also full of unexpected twists and turns, resulting from constant disputes over its principles. One is astonished by the consistent attitude of Hans Frank. He demanded not only a separate German-language radio station for the General Government but also a broad spectrum of broadcasts in Polish. He failed in convincing the authorities in Berlin to agree to this idea.

Keywords: radio broadcasting in the Third Reich, Hans Frank, Joseph Goebbels, General Government, Krakow, Reichs-Rundfunk-Gesellschaft, cultural discrimination.

II wojna światowa w eterze zaczęła się na długo przed tym, zanim pancernik Schleswig-Holstein ostrzelał Westerplatte. Można by pokusić się nawet o stwierdzenie, że jej uwertura miała miejsce w 1926 r., kiedy to niemieckie państwowe przedsiębiorstwo radiofoniczne Reichs-Rundfunk-Gesellschaft 
(RRG) skorumpowało Senat Gdańska, proponując mu stream programu radiowego z Królewca po dumpingowej cenie ${ }^{1}$. Uczyniono to zapewne już wówczas w przekonaniu, że radiofonia może stać się ważnym elementem w procesie walki o przyłączenie tego miasta do Rzeszy. I rzeczywiście rozgłośnia gdańska przed wojną już nigdy nie osiagnęła redakcyjnej samodzielności. Wzięła natomiast aktywny udział w przygotowaniach propagandowych do II wojny prowadzonych przez niemieckie ministerstwo propagandy Reichsministerium für Volksaufklärung und Propaganda (RMVP), kierowane przez Josepha Goebbelsa. Uczestniczyła czynnie w trudnej do zaakceptowania histerii o rzekomym zagrożeniu mniejszości niemieckiej w Polsce. Kolportowano w jej ramach absurdalne pomówienia, a niemieckim dziennikarzom zabroniono nawet weryfikowania ich wiarygodności. Rozgłośnia gdańska też w pierwszych dniach wojny była szczególnie aktywna. 1 IX 1939 o godz. 4.45 , jako pierwsza, poinformowała słuchaczy o rozpoczęciu działań wojennych. Natomiast jeszcze przed przemówieniem Adolfa Hitlera w Reichstagu i przed wiadomościami o godz. 10.00 rozgłośnia gdańska zapowiedziała się słuchaczom jako Reichssender Danzig².

Centrum przygotowań do wojny znajdowało się jednak w stolicy Dolnego Ślaska, Wrocławiu. Ze względu na położenie geograficzne Reichssender Breslau stała się centrum produkcji audycji skierowanych do Niemców mieszkających na wschód od granic Rzeszy. Od początku 1935 r. wprowadzono na antenę tej rozgłośni cykl audycji Deutsche im Ausland, hört zu (Niemcy za granicami, stuchajcie). I rzeczywiście wśród słuchaczy za granicami Rzeszy cieszyła się dużą popularnością ${ }^{3}$. W czerwcu 1939 r. stworzono kolejną taka audycję, pt. Schlesische Heimatdienst (Ślaska stużba małej ojczyźnie), emitowaną o godz. 19.55. Była ona pełna agresywnej, antypolskiej propagandy ${ }^{4}$. Między innymi na potrzeby tej audycji poproszona Ambasadę Niemiec w Warszawie o zbieranie dowodów na antyniemieckie ekscesy w Polsce ${ }^{5}$. Natomiast we wrześniu 1939 Reichssender Breslau emitowała pięć razy dziennie audycje po polsku i skierowane do polskiego słuchacza, pt. Czy to nie jest dziwne. Audycja zaczynała się od czołówki zbudowanej na motywach Halki Stanisława Moniuszki. Jej celem była demobilizacja zarówno polskiej armii, jak i całego społeczeństwa polskiego ${ }^{6}$.

${ }^{1}$ Bundesarchiv (dalej: BA), R 78/617, Abkommen Post und Telegrafenverwaltung der Freien Stadt Danzig und Ostmarken Rundfunk, 1.07.1926, k. nlb.

2 A. Diller, Rundfunkpolitik im Dritten Reich, München 1980, s. 261.

${ }^{3}$ H.R. Fritsche, Nationalismus und Widerstand im Schlesischen Rundfunk, w: Nationalsozialismus und Widerstand in Schlesien, red. L. Bossle, G. Keil, J. Menzel, E. Schulz, Sigmaringen 1989, s. 131.

${ }^{4}$ A. Diller, op. cit., s. 298.

${ }^{5}$ Politisches Archiv des Auswärtigen Amtes (dalej: PAAA), R 104122, Der Staatssekräter Weizsäcker an die Botschaft in Warschau, 13.08.39 (Politische Abteilung, Az. Polen Po 2 E: Politische Beziehungen zu Polen - Gegenseitige Minderheitenerklärungen, Bd. 2).

${ }^{6}$ H.R. Fritsche, Nationalismus und Widerstand im Schlesischen Rundfunk..., s. 133. 
W pierwszej połowie października rozgłośnia we Wrocławiu emitowała po polsku (godz. 6.40, 11.40, 14.30, 17.10 oraz 22.20) dziesięciominutowe audycje informacyjne. W tym samym czasie rozgłośnia w Królewcu nadawała po polsku (o 20.15 i 22.15) dwudziestominutowe audycje informacyjne i jedna publicystyczną audycję wieczorna pod niemieckim tytułem Plauderei (Swobodne rozmowy) o godz. $23.05^{7}$.

Tu dodać trzeba, że w polskim dyskursie publicystycznym często wracaja wydarzenia, które przeszły do historii jako prowokacja gliwicka. Była ona przypuszczalnie wymyślona przez lokalne władze. Nie została skonsultowana ani z intendantem ${ }^{8}$ Rzeszy Heinrichem Glasmeierem, ani z RMVP. Dlatego było to w rzeczywistości wydarzenie pozbawione jakiegokolwiek znaczenia ${ }^{9}$. Choć znalazła ona swoje odbicie w berlińskich mediach ${ }^{10}$, to nie pojawiły się na jej temat poważniejsze komentarze. Krótkie notatki na ten temat opublikowano w prasie lokalnej po kilku dniach. Informowano w nich, że polskie słowa na antenie niemieckiego radia miały wywołać panikę w powiecie gliwickim w obawie przez inwazja polskiej armii na terytorium Rzeszy ${ }^{11}$.

$\mathrm{W}$ trakcie działań wojennych toczonych na terytorium Polski kompanie prasowe $^{12}$ zajmowały kolejne regionalne rozgłośnie radia. Wbrew prawu międzynarodowemu emitowano na ich częstotliwościach dalej polski program, posługując się nawet ich sygnałami dźwiękowymi, jak hejnałem z wieży mariackiej czy pieśnią Legionów My, Pierwsza Brygada ${ }^{13}$. Cel tych programów stanowiło tworzenie systemu dezinformacji i chaosu.

7 Program radiowy, „Der Deutsche Rundfunk” 1939, nr 40, s. nlb.

8 Termin istniejący do dziś w niemieckiej radiofonii na określenie funkcji dyrektora i kierownika artystycznego rozgłośni radiowej czy telewizyjnej. Termin taki występuje również w teatrze.

${ }_{9}$ H.R. Fritsche, Was am Vorabend des zweiten Weltkrieges in Gleiwitz wirklich geschah, „Fernseh-Informationen” 1979, nr 14, s. 337-339; idem, Was am Vorabend des zweiten Weltkrieges in Gleiwitz wirklich geschah, „Fernseh-Informationen” 1979, nr 15, s. 359-361; idem, Was am Vorabend des zweiten Weltkrieges in Gleiwitz wirklich geschah, „Fernseh-Informationen” 1979, nr 16, s. 381-383; zob. też: A. Spiess, H. Lichtenstein, Das Unternehmen Tannenberg, der Anlass zum zweiten Weltkrieg, Wiesbaden 1979, s. 129-155.

10 Sender Gleiwitz besetzt. Polen drangen in den Senderaum ein - Blutig hinausgeworfen, „Berliner Lokal-Anzeiger” 1939, nr 209, s. 1 (1.09.1039).

${ }^{11}$ K. Wagenführ, Die Septemberereignisse im Rundfunk, „Der Deutsche Rundfunk” 1939, nr 37, s. 2.

${ }^{12}$ Wydzielone jednostki wojskowe, których żołnierzami i oficerami byli wyłącznie dawni pracownicy mediów. Realizowały one m.in. zadania techniczno-logistyczne, jak nadawanie programu radiowego czy drukowanie gazet i materiałów propagandowych. W kompanie prasowe zaangażowani byli także doświadczeni dziennikarze, którzy tworzyli samodzielnie przekazy medialne, jak również relacje frontowe dla cywilnych mediów. Zob. S. Fikus. Radiofonia w III Rzeszy. Studium ideowego zniewolenia, Katowice 2018, s. $81-82,152-153$.

${ }^{13}$ L. Dobroszycki, Die legale polnische presse im Generalgouvernement 1939-1945, München 1977, s. 14 i n. 
W pierwszym momencie wydawało się, że niemieckie władze okupacyjne prowadzić będą liberalna politykę radiofoniczna, w ramach której kultura i język polski znajda swoje istotne miejsce. RMVP poczyniło w tym kierunku wielopłaszczyznowe kroki. Wyznaczono nawet osobę odpowiedzialna za produkcję polskojęzycznych programów. Miał to być Ferdinand Türmer ${ }^{14}$. Nadzieje te okazały się całkowicie płonne, bo już w połowie października $1939 \mathrm{r}$. założenie programowe zmieniono całkowicie. 16 X $1939 \mathrm{r}$. wprowadzono całkowity zakaz używania języka polskiego na antenie $R R G^{15}$. Natomiast programy muzyczne, emitowane przez dawne polskie rozgłośnie regionalne, miały dostosować się wyłącznie do gustów i oczekiwań niemieckich żołnie$\mathrm{rzy}^{16}$. Do społeczności polskiej informacje winny docierać poprzez megafony i kontrolowana, reżimową prasę ${ }^{17}$.

Niemiecka polityka radiofoniczna była niekonsekwentna i chwiejna, co wynikało z trwającego prawie całą okupację konfliktu pomiędzy Hansem Frankiem a RMVP. Frank uważał się za suwerena odpowiedzialnego za całokształt polityki w okupowanej Polsce. Stał na stanowisku, że na terenie Generalnej Guberni panuje inna sytuacja narodowa, polityczna i społeczna jak w pozostałej części Rzeszy. Dlatego domagał realizacji innego, własnego programu radiowego ${ }^{18}$.

Na jego powstanie RMVP konsekwentnie się nie zgadzało. Dzięki skutecznym zakazom importu gazet i słuchania obcych stacji udało się stworzyć w Rzeszy zamknięta przestrzeń informacyjna. Dzięki temu RMVP, bez obaw o podważenie swojej wiarygodności, mogło kreować najbardziej absurdalne wyobrażenia o sytuacji w Rzeszy, relacjach międzynarodowych czy zmianach na frontach. A ewentualne, niekontrolowane informacje płynace z Krakowa mogłyby być dla tych mistyfikacji zagrożeniem. RMVP domagało się retransmisji w Polsce programów realizowanych w Berlinie bez ingerencji ${ }^{19}$.

Miały one na początku wojny niejako dwa wydania. Z jednej strony był to program Deutschlandsender, emitowany z Königs Wusterhausen na falach długich, zdominowany przez muzykę poważna. Inny charakter miał Reichsprogramm (Program Rzeszy), który powstał ze zblokowania programów

${ }^{14}$ A. Diller, op. cit., s. 402.

${ }_{15}$ M.J. Kwiatkowski, Polskie Radio w konspiracji 1939-1944, Warszawa 1989, s. 93.

${ }_{16}$ A. Diller, op. cit., s. 404.

${ }^{17}$ Das Diensttagebuch des deutschen Generalgouverneurs in Polen 1939-1945, red. W. Präg, Stuttgart 1975, s. 62 (wpis z 8.11.1939).

18 Ten konflikt Franka z RMVP o wpływ na radiofonie w Generalnej Guberni będzie trwać całą okupację. Archiwum Instytutu Pamięci Narodowej w Warszawie (dalej: AIPN), GK 95/1, Hans Frank, Diensttagebuch, 15.11.1939, k. 67; ibidem, GK 95/4, 4.05.1940, k. 366; ibidem, GK 95/5, Hans Frank, Diensttagebuch, 9.09.1940, k. 833; ibidem, GK 95/13, Hans Frank, Diensttagebuch, 26.11.1941, k. 1106; ibidem, Hans Frank, Diensttagebuch, 27.10.1942, k. 1165; ibidem, GK 95/29, Hans Frank, Diensttagebuch, 19.10.1943, k. 1051.

19 A. Diller, op. cit., s. 406. 
niemieckich rozgłośni regionalnych, przed wojną produkujących własne programy. Od początku wojny zmuszano je do reemisji programu rozgłośni berlińskiej i mogły co najwyżej wypełniać skromne regionalne pasma rozdzielne ${ }^{20}$. Reichsprogramm nadawany był na falach średnich i zdominowany przez muzykę rozrywkową ${ }^{21}$.

Na płaszczyźnie ideologicznej obie rozgłośnie niczym się od siebie nie różniły, a kluczowe dla reżimu programy publicystyczno-informacyjne emitowane były w obu programach jednocześnie. Ale już latem 1940 r. zlikwidowano odrębny program na falach długich. Deutschlandsender retransmitował Reichsprogramm. Z czasem jednak wycofano się z tej decyzji. Od 1 III $1942 \mathrm{r}$. wprowadzono ponownie oddzielny program popołudniowy na falach długich. Nazwano go Doppelprogramm (program uzupełniający) i nadawano początkowo od 17.10 do 18.30 i potem od 20.15 do $22.00^{22}$. Emitujaca na falach długich rozgłośnia Deutschlandsender w następnych miesiącach odzyskiwała coraz więcej samodzielności ${ }^{23}$.

W okupowanej Polsce 18 X 1939, bez konsultacji z gubernatorem Frankiem, Goebbels dokonał reorganizacji struktur dawnej polskiej radiofonii ${ }^{24}$. Rozgłośnia w Poznaniu pozostała na swojej dawnej długości fal 345,6 m, ale podporządkowano ją bezpośrednio Reichssender Berlin. Sprowadzono ją do roli stacji przekaźnikowej. Program rozgłośni gdańskiej miał być emitowany na falach średnich o długościach 304,3 jako Danzig I (Gdańsk I) oraz 230,2 jako Danzig II (Gdańsk II). Jej to podlegała odtąd dawna rozgłośnia toruńska, która sprowadzono do roli stacji przekaźnikowej ${ }^{25}$.

$\mathrm{Na} z n a c z e n i u$ zyskała Reichssender Breslau. Podporządkowano jej dla przykładu dawny Reichssender Böhmen ${ }^{26}$, który emitowany był z Opawy (wówczas Troppau). Od rozgłośni wrocławskiej uzależniono, wspomnianym wcześniej rozporządzeniem Goebbelsa z 18 X 1939 r., również nowo utworzoną rozgłośnię w Katowicach - Sender Kattowitz. Miała on emitować program na dawnych częstotliwościach nadajnika Praga II. Rozgłośni katowickiej przyznano jednak tylko bardzo krótkie pasma rozdzielne i w zasadzie sprowadzona została również do stacji przekaźnikowej rozgłośni wrocławskiej ${ }^{27}$.

${ }^{20}$ Pasmo rozdzielne to czas antenowy, w którym rozgłośnia regionalna wyłącza program centralny i emituje w tym czasie swoje własne audycje. Po ich zakończeniu wraca do programu centralnego.

${ }^{21}$ A. Diller, op. cit., s. 383; S. Fikus, Radiofonia w III Rzeszy..., s. 118.

${ }_{22}$ Chronik des Weltrundfunks, „Welt-Rundfunk” 1942, nr 2, s. 87.

${ }^{23}$ BA, R 55/425, Doppelprogramm für die Programmwoche vom 19.-25.3.1944, k. 170 i n.; S. Fikus, Radiofonia $w$ III Rzeszy..., s. 142.

${ }_{24}$ Die Gliederung des Rundfunks im Osten. Drei Sendebezirke, Hauptsender Lodz, „Der Deutsche Rundfunk" 1939, nr 50, s. nlb.

${ }^{25}$ Ibidem.

${ }^{26}$ M.J. Kwiatkowski, op. cit., s. 92.

${ }^{27}$ Die Gliederung des Rundfunks im Osten..., s. nlb. 
Na skutek tej reorganizacji intendant rozgłośni wrocławskiej Hans-Otto Fricke stał się kolejnym konkurentem Franka w procesie kształtowania polityki radiofonicznej ${ }^{28}$. Reichssender Breslau była w okupowanej Polsce dobrze słyszalna. A Fricke upatrywał dla siebie szansy w kreowaniu programu dla Niemców mieszkających w Polsce. Ambicje te stanowiły jednak powód ciągłej irytacji Franka, który doszukiwał się w tych planach naruszenia jego własnej suwerenności ${ }^{29}$.

Głębokie niezadowolenie Franka wywołał również fakt, że Goebbels powołał na intendanta radiofonii w Generalnej Guberni i swojego pełnomocnika Hansa Krieglera ${ }^{30}$. Decyzja ta nie była konsultowana z Frankiem i wywołała w Krakowie irytację $e^{31}$.

Siedzibą intendanta Krieglera miała być Łódź, ponieważ w Berlinie wychodzono z założenia, że właśnie tam $\mathrm{w}$ okresie międzywojennym stworzono najlepsza infrastrukturę produkcyjna w Polsce ${ }^{32}$. Zbudowano tu też wcześniej nadajnik o stosunkowo dużym zasięgu ${ }^{33}$. Z niego też rozpoczęto retransmisje Reichsprogramm na falach $224 \mathrm{~m}$. Ponieważ program ten zawierał swoje pasmo rozdzielne, nazwano go Litzmannstadt II (Łódź II). Ten sam program retransmitowano przez warszawski nadajnik na falach średnich $216,8 \mathrm{~m}$. W myśl planów RMVP program produkowany w Łodzi miał być retransmitowany jako Litzmannstadt II przez nadajnik w Krakowie na fali $293,5 \mathrm{~m}^{34}$, a od lipca 1941 również przez rozgłośnię lwowską na długościach fali $377,4 \mathrm{~m}^{35}$.

Program berliński z pasem rozdzielnym retransmitowano również na falach długich $1339 \mathrm{~m}$ i nazwano go Litzmannstadt $\mathrm{I}^{36}$. Nie trwało to jednak długo, ponieważ tym razem Frank, bez konsultowania swojej decyzji z RMVP, przekształcił ten program w listopadzie 1941 r. w nową rozgłośnię Radio Weichsel (Wisła), która nadawała teraz na częstotliwościach Litzmannstadt ${ }^{37}$.

Bardzo szybko Frank został jednak pozbawiony wpływu na tę nową stację, ale której program pozostał stosunkowo niezależny od Reichsprogramm. Rozgłośnia koncentrowała się na emisji różnego rodzaju audycji rozrywkowych i stanowiła w pejzażu niemieckiej radiofonii rodzaj trzeciego programu. Był on skierowany głównie do żołnierzy Wehrmachtu, co wynikało również z jej położenia geograficznego. Podobny charakter miały też rozgłośnie Luxemburg

${ }^{28}$ H.R. Fritsche, Nationalismus und Widerstand im Schlesischen Rundfunk..., s. 132.

29 A. Diller, op. cit., s. 407.

${ }^{30}$ Die Gliederung des Rundfunks im Osten..., s. nlb.

31 AIPN, GK 95/1, Hans Frank, Diensttagebuch, 15.11.1939, k. 67. Zob. też: M.J. Kwiatkowski, op. cit., s. 94.

${ }^{32}$ A. Diller, op. cit., s. 405.

${ }^{33}$ AIPN, GK 95/2, Hans Frank, Diensttagebuch, 12.04.1940, k. 130.

${ }^{34}$ Die Gliederung des Rundfunks im Osten..., s. nlb.

${ }^{35}$ Der deutsche Rundfunk im Lemberg, „Reichsrundfunk” 1941-1942, nr 18, s. 364.

${ }^{36}$ Die Gliederung des Rundfunks im Osten..., s. nlb.

${ }^{37}$ AIPN, GK 95/13, Hans Frank, Diensttagebuch, 26.11.1941, k. 1106. 
i Alpen w austriackim Dobl. Na znacznych częściach Rzeszy nie były one jednak słyszalne ${ }^{38}$.

Jako kompromis w sporze między Frankiem i RMVP postanowiono, że w ramach rozgłośni Radio Weichsel emitowany będzie codzienny program informacyjny Das Tagesecho des Generalgouvernements, poświęcony wydarzeniom w okupowanej Polsce. Również na falach Litzmannstadt II nadawano codziennie wiadomości i 90 minut własnego programu ${ }^{39}$. Ale Frank wraz ze swa administracja domagał coraz większego wpływu na kształt tego programu ${ }^{40}$.

W sporach z RMVP niewątpliwym sukcesem Franka było przeniesienie centrum produkcji programów radiowych z Łodzi do Krakowa. Początkowo nie istniała tam wystarczająca infrastruktura techniczna. Stąd w pierwszych miesiącach okupacji programy radiowe na zlecenie Franka realizowano głównie $\mathrm{w}$ rozgłośni $\mathrm{w}$ Katowicach ${ }^{41}$. Była ona podporządkowana organizacyjnie Reichssender Breslau, z którego kierownictwem Frank popadł w konflikt. Kiedy spory te się nasiliły, w listopadzie $1941 \mathrm{r}$. nakazał on zerwanie jakiejkolwiek współpracy z rozgłośnią we Wrocławiu ${ }^{42}$.

Była ona Frankowi od dawna już niepotrzebna, ponieważ zmodernizowano infrastrukturę w Krakowie. Od 1 IV 1940 rozgłośnia krakowska zaczęła produkcję prostych audycji, ale już kilka dni później, 6 V 1940 r., uruchomiono produkcję kolejnych, niezależnych od Berlina formatów ${ }^{43}$.

Dziwi natomiast fakt, że Frank i Kriegler nie znaleźli wspólnego języka, ponieważ $w$ gruncie rzeczy stawiali sobie bardzo podobne cele. Obaj dążyli do stworzenia $\mathrm{w}$ Polsce systemu odrębnej radiofonii z niezależnym programem i własnym serwisem informacyjnym. Rozbieżności między Krieglerem i Frankiem dotyczyły raczej drugorzędnego pytania, czy centrum takiej nowej rozgłośni miałoby się znajdować w Krakowie, czy w Łodzi ${ }^{44}$. Pewną rolę mogły również odegrać napięcia pomiędzy nimi, które tworzył sam Goebbels.

Interesujacy jest fakt, że spory kompetencyjne w Generalnej Guberni podsycał także szef prasowy kancelarii Hitlera (Reichspressechef) Jacob Otto Dietrich, który również domagał się wpływu na kształt programu radiowego $\mathrm{w}$ okupowanej Polsce ${ }^{45}$. Ważnym graczem w tych sporach była niemiecka poczta odpowiedzialna za całą infrastrukturę techniczną ${ }^{46}$.

${ }^{38}$ W. Schütte, Rationalität und Föderalismus im Rundfunk. Die geschichtliche Entwicklung in Deutschland 1923-1945, Frankfurt am Main 1971, s. 186 i n.; zob. też: K. Dussel, Deutsche Rundfunkgeschichte, Konstanz 2010, s. 97.

39 AIPN, GK 95/4, Hans Frank, Diensttagebuch, 4.05.1940, k. 366.

${ }^{40}$ Ibidem, GK 95/2, Hans Frank, Diensttagebuch, 12.04.1940, k. 130.

${ }^{41}$ Ibidem, Hans Frank, Diensttagebuch, 12.04.1940, k. 130.

${ }^{42}$ Ibidem, GK 95/13, Hans Frank, Diensttagebuch, 26.11.1941, k. 1106.

${ }^{43}$ M.J. Kwiatkowski, op. cit., s. 94.

${ }^{44}$ AIPN, GK 95/1, Hans Frank, Diensttagebuch, 15.11.1939, k. 67.

${ }_{45}$ A. Diller, op. cit., s. 405.

${ }^{46}$ AIPN, GK 95/1, Hans Frank, Diensttagebuch, 15.11.1939, k. 67. 
Frank konsekwentnie dażył do stworzenia zależnej od siebie rozgłośni radiowej z siedzibą w Krakowie. Chciał, by podporząlkowane jej zostały redakcje w Warszawie i Lwowie. Z rozgłośni łódzkiej zamierzał zrezygnować całkiem. Program radiowy Generalnej Guberni miał być w planach Franka całkowicie odrębny i niezależny od RMVP ${ }^{47}$.

Kiedy spór z RMVP wydawał się nie do rozwiązania, Frank zdecydował się na jednostronny krok. 26 XI 1941 wydał rozporządzenie o powołaniu nowej rozgłośni krakowskiej i na jej intendanta wyznaczył swojego urzędnika Erwina Jansena $^{48}$. Decyzji Franka RMVP jednak nie zaakceptowało. Goebbels odwołał Jansena i wyznaczył na jego miejsce w pełni od siebie zależnego Boscha.

To w oczywisty sposób zantagonizowało sytuację jeszcze bardziej. Podczas jego wizyty u Franka doszło do ostrej wymiany zdań, w której gubernator wyrażał oburzenie faktem, że został pozbawiony wpływu na kształt programu ${ }^{49}$.

Był zirytowany, że w ogólnoniemieckich wiadomościach w ogóle nie ukazywały się wiadomości na temat Generalnej Guberni ${ }^{50} \mathrm{i}$ ubolewał nad trudnościami czynionymi przez RMVP przy emisji własnych audycji. Proponował rozbudowanie audycji Das Tagesecho des Generalgouvernements o elementy publicystyczne. Miały się w niej znaleźć także wiadomości kulturalne, gospodarcze, polityczne i sportowe.

Frank obawiał się, że również i tę inicjatywę RMVP zablokuje ${ }^{51}$. Wyrażał także niezadowolenie, że w przypadku koncertów symfonicznych realizowanych w Krakowie i transmitowanych przez rozgłośnię ogólnoniemiecką był pozbawiony nawet wpływu na obsadę dyrygenta i skład orkiestry ${ }^{52}$.

$\mathrm{Na}$ spór o kształt radiofonii w Generalnej Guberni wpływ miała klęska pod Stalingradem. Wydarzenie to dla polityki informacyjnej RMVP stanowiło całkowity przełom. Kiedy do lutego 1943 r. media wmawiały społeczeństwu niemieckiemu, że wojna jest harcerska przygoda pozbawioną większych niebezpieczeństw ${ }^{53}$, to później audycje RRG zmieniły całkowicie swój charakter ${ }^{54}$. Od wiosny 1943 r. starano się społeczeństwu niemieckiemu uświadomić spektrum zagrożeń związanych z wojną. Lęk przed zemstą aliantów miał być główną motywacją do wojennego wysiłku ${ }^{55}$.

Ta głęboka przemiana polityki programowej RMVP spowodowała, że ministerstwo kierowane przez Goebbelsa zaczęło wykazywać więcej zrozumienia dla żądań płynących z Krakowa. Jednym z symptomów tej ewolucji była

\footnotetext{
${ }^{47}$ Ibidem, GK 95/4, Hans Frank, Diensttagebuch, 4.05.1940, k. 366.

${ }^{48}$ Ibidem, GK 95/13, Hans Frank, Diensttagebuch, 26.11.1941, k. 1106.

${ }^{49}$ Ibidem, GK 95/21, Hans Frank, Diensttagebuch, 27.10.1942, k. 1165.

${ }^{50}$ Ibidem, GK 95/29, Hans Frank, Diensttagebuch, 19.10.1943, k. 1051.

${ }^{51}$ Ibidem, GK 95/13, Hans Frank, Diensttagebuch, 27.10.1942, k. 1165.

${ }^{52}$ Ibidem, GK 95/21, Hans Frank, Diensttagebuch, 27.10.1942, k. 1165.

${ }^{53}$ G. Gülicher, Der Zeitspiegel im Jahre 1942, „Reichsrundfunk” 1942, nr 23, s. 447 i n.

${ }^{54}$ K. Kraft, Das Wort von der Front, „Reichsrundfunk” 1943, nr 19, s. 361.

${ }^{55}$ BA, R 58/959, Bericht SD Stuttgart, 19.05.43, k. 75.
} 
rezygnacja z Łodzi jako centralnego punktu sterowania programem radiowym w Generalnej Guberni. Nadajnik w tym mieście podporządkowany został strukturom berlińskim i stał się stacją przekaźnikową dla Reichsprogramm ze stolicy Niemiec ${ }^{56}$.

Decyzja ta nie osłabiła jednak siły konfliktu pomiędzy RMVP a rządem Generalnej Guberni. Podczas kolejnej wizyty intendanta Boscha u Franka w październiku 1943 r. doszło znowu do ostrej wymiany zdań na temat stworzenia niezależnej radiofonii w Generalnej Guberni ${ }^{57}$. Frank zarzucił $\mathrm{mu}$, że ogranicza jego suwerenność na powierzonym mu terenie. Miała to być dla gubernatora sytuacja nie do zaakceptowania i dlatego kategorycznie domagał się wpływu na programy emitowane w okupowanej Polsce ${ }^{58}$. Po raz kolejny żądał stworzenia odrębnej, podporządkowanej mu radiofonii w Generalnej Guberni. Intendant Bosch sprzeciwiał się temu, argumentując, że w okupowanej Polsce niewiele się dzieje i nie będzie wystarczającej liczby tematów do zaproponowania słuchaczom. Oprócz tego zwracał uwagę na ogromny wysiłek organizacyjny przy tworzeniu takiej rozgłośni, jako że każda audycja emitowania w Polsce musiałaby wcześniej być uzgodniona z RMVP w Berlinie ${ }^{59}$. Inna rzecz, że dokładnie tego Frank chciał uniknać.

Jeden z centralnych konfliktów pomiędzy administracją Franka i ministerstwem kierowanym przez Goebbelsa dotyczył również żądania produkcji i emisji programów polskojęzycznych. Niechęć RMVP do tego postulatu wynikała z fundamentalnych założeń polityki wobec społeczności polskiej. W Berlinie dominował pogląd o konieczności prowadzenia restrykcyjnej polityki wobec społeczeństwa polskiego. Zakładała ona głęboką dyskryminację edukacyjna i kulturalna. Polakom zakazano uczęszczania do kina czy teatru, a tym bardziej chciano im uniemożliwić dostęp do polskojęzycznego radia ${ }^{60}$. W tamtych czasach było ono stosunkowo młodym medium i symbolem nowoczesnej kultury masowej - takiej, od jakiej zamierzano środowiska polskie trzymać z daleka. Zdaniem RMVP radio miało być po niemiecku i tylko dla Niemców ${ }^{61}$.

Już 1 X 1939 r. wydano pierwsze nakazy odebrania polskiej ludności cywilnej radioodbiorników ${ }^{62}$. Obiecywano sobie po nim również uniemożliwienie Polakom słuchania obcych stacji ${ }^{63}$. Zwolennikiem najbardziej radykalnego ich odebrania był sam Goebbels ${ }^{64}$. Wolę tę potwierdziło rozporządzenie Hitlera z 10 X 1939 r. Odbiorniki zatrzymać mogli wyłącznie przedstawiciele

\footnotetext{
${ }^{56}$ Sender Litzmannstadt, „Rundfunkarchiv” 1940, nr 8, s. 270.

57 AIPN, GK 95/29, Hans Frank, Diensttagebuch, 19.10.1943, k. 1052.

58 Ibidem, k. 1053.

${ }^{59}$ Ibidem, k. 1052.

${ }^{60}$ Das Diensttagebuch des deutschen Generalgouverneurs in Polen..., s. 54 (wpis z 31.10.1939).

${ }^{61}$ L. Dobroszycki, op. cit., s. 15.

${ }^{62}$ Ibidem, s. 15; M.J. Kwiatkowski, op. cit., s. 93.

${ }^{63}$ Das Diensttagebuch des deutschen Generalgouverneurs in Polen..., s. 62 (wpis z 8.11.1939).

${ }^{64}$ L. Dobroszycki, op. cit., s. 61.
} 
mniejszości niemieckiej. Wkrótce jednak części osób oddano je, zwracając uwagę na drakońskie kary, jakie obowiązywały w Rzeszy za słuchanie obcego radia ${ }^{65}$. Liberalizacja polityki radiofonicznej nie trwała jednak długo. Pod naciskiem Goebbelsa już 15 XII 1939 r. Frank wydał kolejne rozporządzenie o rekwizycji odbiorników radiowych ${ }^{66}$. Zgodnie z nim do 25 I 1940 r. miały zostać oddane wszystkie urządzenia. Z obowiązku tego zwolniono część Ukraińców i górali, których uważano za odrębną część społeczeństwa polskiego. Bilans tej akcji nie był zadowalający, ponieważ okazało się, że w samej tylko Warszawie do 2 III 1940 r. oddano zaledwie 60\% urządzeń ${ }^{67}$.

Żądaniom odebrania odbiorników radiowych społeczeństwu polskiemu sprzeciwiał się Frank. I to z jego inicjatywy ostatecznie w kwietniu 1940 r. zliberalizowano tę politykę ${ }^{68}$. By mieć takie urządzenie, jego potencjalny właściciel musiał jednak wystapić do niemieckiej administracji o odpowiednie pozwolenie. Ku wielkiemu rozczarowaniu władz okupacyjnych do września 1940 r. wniosków o zgodę na posiadanie i słuchanie radia w całej Generalnej Guberni wpłynęło zaledwie $500^{69}$. Stąd oficjalnie społeczność polska nigdy nie posiadała powszechnie odbiorników. Mieli je w zasadzie tylko Niemcy. W szczytowym momencie, w styczniu 1943 r., zarejestrowanych w Generalnej Guberni było zaledwie 30 tys. urządzeń ${ }^{70}$.

Niezależnie od dyskusji na temat prawa do posiadania odbiorników, Frank domagał się od RMVP również zgody na produkcję nowych formatów informacyjnych i publicystycznych $\mathrm{w}$ języku polskim ${ }^{71}$. Postulował także zatrudnienie polskich lektorów i spikerów ${ }^{72}$. Dla realizacji audycji w języku polskim powołał z własnej woli nawet odrębny referat ${ }^{73}$. Frank dopominał się też, by nadawano transmisje - według niego - ważnych wydarzeń politycznych i kulturalnych ${ }^{74}$, np. pierwszego koncertu polskiej orkiestry symfonicznej 14 X 1940 r. w Krakowie ${ }^{75}$.

${ }^{65}$ Ibidem, s. 15.

${ }^{66}$ Rozporządzennie o konfiskacie i oddaniu aparatów radiowych z 15.12.1939, „Verordnungsblatt des Generalgouverneurs für die Besetzten Polnischen Gebiete” 1939, nr 13, s. 225.

${ }^{67}$ Das Diensttagebuch des deutschen Generalgouverneurs in Polen..., s. 132 (wpis z 2.03.1940; ze 140 tys. zameldowanych odbiorników oddano niemieckim urzędom 87 tys.). Zob. też: M.J. Kwiatkowski, op. cit., s. 95.

${ }^{68}$ Rozporządzenie w sprawie posiadania i używania sprzętu radiofonicznego w Generalnym Gubernatorstwie z 13.04.1940, „Verordnungsblatt des Generalgouverneurs für die Besetzten Polnischen Gebiete” 1940, nr 35, s. 167.

${ }^{69}$ A. Diller, op. cit., s. 404.

70 Weltrundfunk 1943/2, s. 89, cyt. za: A. Diller, op. cit., s. 404.

${ }^{71}$ AIPN, GK 95/5, Hans Frank, Diensttagebuch, 9.09.1940, k. 833.

${ }^{72}$ Ibidem, k. 833.

${ }^{73}$ A. Diller, op. cit., s. 405.

${ }^{74}$ AIPN, GK 95/1, Hans Frank, Diensttagebuch, 15.11.1939, k. 67; ibidem, GK 95/4, 4.05. 1940, k. 366.

${ }^{75}$ Ibidem, GK 95/5, Hans Frank, Diensttagebuch, 9.09.1940, k. 833. Koncert ten odbył się przypuszczalnie w ramach inauguracji Filharmonii Generalnej Guberni 14 X 1940 r. 
W dyskusjach nad obecnościa polskich audycji przełomem okazały się także wydarzenia pod Stalingradem. Elity narodowosocjalistyczne w Berlinie zrozumiały, że napięcia w kontaktach ze społeczeństwem polskim mogą negatywnie wpływać na możliwości ekonomiczne i militarne III Rzeszy. Dlatego też podejmowano różnego rodzaju, najczęściej niekonsekwentnie, działania mające na celu neutralizację pól napięc ${ }^{76}$. Rozważano dopuszczenie polskich obywateli do wyższych urzędów w Generalnej Guberni ${ }^{77}$. Pojawiły się postulaty, by umożliwić społeczeństwu polskiemu uczestnictwo w życiu kulturalnym ${ }^{78}$.

W 1943 r. podjęto w Berlinie działania na rzecz rozszerzenia pasm audycji po polsku ${ }^{79}$. RMVP wyznaczyło nawet osobę odpowiedzialną za produkcję formatów w tym języku. Był nią Niemiec o nazwisku Styrer ${ }^{80}$. Zezwolono również na obramowanie polskich audycji polską muzyką ${ }^{81}$.

Pod koniec 1943 r. w Generalnej Guberni emitowano codziennie w języku polskim na falach średnich cztery wydania wiadomości oraz dwukrotnie na falach długich przez rozgłośnię Weichsel ${ }^{82}$. W tym czasie Frank domagał się nawet powołania osobnej agencji informacyjnej, która miałaby przygotowywać atrakcyjne $\mathrm{w}$ formie polskojęzyczne programy informacyjne, publicystyczne i kulturalne ${ }^{83}$. Zwłaszcza te ostatnie uważał za istotne ${ }^{84}$. W dyskusjach z RMVP Frank zwracał uwagę, że niemiecka radiofonia produkuje polskojęzyczne programy skierowane do polskich żołnierzy w alianckich armiach. Niektóre fragmenty tych audycji miałyby się nadawać do emisji na terenie Generalnej Guberni ${ }^{85}$.

Postulaty dalszego rozszerzenia pasm emisyjnych programów w języku polskim wzbudzały jednak poważne kontrowersje. Przeciwko nim opowiadały się kancelaria Rzeszy i aparat terroru. W zupełnie nieoczekiwany sposób wspólny język znalazł krakowski rząd Generalnej Guberni z RMVP w Berlinie. Podobnie jak Frank, sam Goebbels był przekonany o konieczności prowadzenia łagodniejszej polityki wobec społeczeństwa polskiego. Zmianę tę dostrzegano w prasie reżimowej, w której teraz pracować mogło więcej Polaków ${ }^{86}$. Ostatecznie jednak jakiejś jakościowej zmiany wprowadzania

Zob. S. Lachowicz, Muzyka w okupowanym Krakowie 1939-1945, Kraków 1988, s. 22, 23; T. Wroński, Kronika okupowanego Krakowa, Kraków 1974, s. 122.

${ }^{76}$ Ch. Kleßmann, Die Selbstbehauptung einer Nation. Nationalsozialistische Kulturpolitik und polnische Widerstandsbewegung im Generalgouvernement 1939-1945, Düsseldorf 1971, s. 31.

77 Ibidem, s. 32.

${ }^{78}$ Ibidem, s. 93.

${ }^{79}$ AIPN, GK 95/29, Hans Frank, Diensttagebuch, 19.10.1943, k. 1051.

${ }^{80}$ Ibidem, GK 95/37, Hans Frank, Diensttagebuch, 17.10.1944, k. 186.

${ }^{81}$ Ibidem, k. 186.

${ }^{82}$ Ibidem, GK 95/29, Hans Frank, Diensttagebuch, 19.10.1943, k. 1052.

${ }^{83}$ Ibidem, k. 1051.

${ }^{84}$ Ibidem, k. 1053.

${ }^{85}$ Ibidem, GK 95/37, Hans Frank, Diensttagebuch, 17.10.1944, k. 186.

${ }^{86}$ Ch. Kleßmann, op. cit., s. 31. 
języka polskiego czy dopuszczenia elementów kultury polskiej na antenie radia w okupowanej Polsce nie dokonano.

W kontekście niemieckiej radiofonii warto też zwrócić uwagę, że przez pewien czas Warszawa była największym centrum produkcji odbiorników radiowych. Postulat zbudowania takiej fabryki zgłaszał Frank już we wrześniu 1940 r., zdając sobie sprawę z niedostatecznej liczby takich urządzeń na terenie Generalnej Guberni ${ }^{87}$.

W kolejnych latach wojny odbiorniki radiowe stawały się coraz bardziej deficytowym towarem. Pojawił się problem z dostępem również do części zamiennych do istniejących urządzeń ${ }^{88}$. By zwiększyć ich produkcję, konieczna była klasyfikacja odbiorników jako przedmiotów ważnych z punktu widzenia prowadzonej wojny (Kriegswichtig). Dopiero wówczas można by przeznaczyć do ich produkcji deficytowe surowce, jak i zwolnienia pracowników ze służby w Wehrmachcie ${ }^{89}$. Ostatecznie zadecydowano, że produkcja ma się odbywać właśnie w Warszawie. W tym celu zorganizowano nowe przedsiębiorstwo Deutsche Rundfunk-Empfänger-Fabrik. 99\% jego udziałów znajdowało się w rękach państwa. Rzeszę w tej spółce reperezentowała Wirtschaftsstelle der Deutschen Rundfunk-Industrie. Śladowymi udziałowcami były cztery inne komercyjne firmy ${ }^{90}$.

Planowano uruchomienie w Warszawie dwóch linii produkcyjnych. Części i podzespoły do odbiorników radiowych produkować miały różne firmy na terenie Generalnej Guberni. Montaż urządzeń winien się rozpocząć już w marcu $1942 \mathrm{r} \cdot{ }^{91}$ Plany te okazały się całkowicie nierealistyczne. Zamierzeń tych nie udało się nawet w niewielkim stopniu zrealizować. Do maja $1942 \mathrm{r}$. skompletowano zaledwie hale produkcyjne. Wynikało to również z faktu, że transport urządzeń produkcyjnych do Polski napotykał wielkie problemy o charakterze logistycznym ${ }^{92}$. W pierwszym roku produkcji zmontowano w Warszawie zaledwie 777428 odbiorników radiowych. Wśród nich było aż 580 tys. urządzeń podwyższonej jakości. Zapotrzebowanie na radia w Rzeszy nie zostało pokryte nawet $\mathrm{w}$ połowie ${ }^{93}$.

${ }^{87}$ AIPN, GK 95/5, Hans Frank, Diensttagebuch, 9.09.1940, k. 833. Zob. też: M.J. Kwiatkowski, op. cit., s. 95.

${ }^{88}$ BA, R 58/181, Meldungen, Nr. 366, 11.03.43, k. 72 i n.

${ }^{89}$ Ibidem, 55/561, Fritzsche an Reichsminister Goebbels, 15.12.1944, k. 158.

90 Były to: Telefunken G.m.b.H., Mende \& Co. G.m.b.H., Georg Budich G.m.b.H. und Hermann Strumpf. Zob. ibidem, 55/401, Reisebericht der nach dem Generalgouvernement entsandten Kommission in Angelegenheiten der Verlegung der Produktion z DKE-Empfängern und Export-Geräten, 13.10.1941, k. 46 i n.; ibidem, Gronefeld an Diewerge, 24.1.1942, k. 75 i n.

${ }^{91}$ Ibidem, Reichministerium für Propaganda und Volksaufklärung an Wirtschaftsstelle der deutschen Rundfunkindustrie, 27.04.1942, k. 10.

${ }_{92}$ Ibidem, Wirtschaftsstelle der deutschen Rundfunkindustrie e. V. an das Reichspropagandaministerium, 1.06.1942, k. $92 \mathrm{i} \mathrm{n.}$

${ }^{93}$ BA, NS 10/310, Staats an Tießler, 26.11.1942, k. nlb. Kwestie produkcji odbiorników zob. S. Fikus, Radiofonia w III Rzeszy..., s. 155 i n. 
W miarę zbliżania się do Polski frontu wschodniego coraz lepiej słyszalne były tutaj rozgłośnie żołnierskie emitujące program radiowy produkowany przez kompanie prasowe. Tą najbardziej znaną rozgłośnią Wehrmachtu stało się chyba Radio Belgrad ${ }^{94}$. Kompanie prasowe tworzyły program zupełnie niezależny od Reichsprogramm, chociaż przejmowały wiele jego elementów dla ułatwienia sobie pracy.

$\mathrm{Z}$ czasem w niemieckiej radiofonii rosła rola kompanii prasowych, które przechwytywały również zadania dywersyjne. Na przykład gdy w Warszawie zamilkła powstańcza rozgłośnia „Błyskawica”, to na jej częstotliwości natychmiast włączył się nadajnik kompanii prasowej, symulujący kontynuację emisji programu w języku polskim. Jej celem było oczywiście wywoływanie nieporozumień i wprowadzanie słuchaczy w błąd ${ }^{95}$. Kompanie prasowe podejmowały również inne zadania, np. w marcu 1944 r. RGG dokonało ewakuacji rozgłośni we Lwowie. Kompania prasowa Wehrmachtu prowadziła dalej emisję niemieckiego programu z nadajnika mobilnego. Przypuszczalnie wierzono w ustabilizowanie się frontu i rychły niemiecki powrót do Lwowa ${ }^{96}$.

Ostatecznie nie udało się Frankowi stworzyć samodzielnej okupacyjnej radiofonii, w której polskojęzyczne audycje odgrywałyby ważną rolę. Łudził się, że pomimo brutalnego terroru mógłby w ten sposób pozyskać przynajmniej część środowisk polskich dla swej okupacyjnej polityki. Rachuby się nie spełniły, a ruch oporu zadawał III Rzeszy ciężkie straty. Polityka kulturalnej dyskryminacji środowisk polskich się do nich również przypuszczalnie przyczyniła.

\section{Streszczenie}

Niemiecka polityka radiofoniczna w Generalnej Guberni obejmowała kilka etapów. Początkowo zamierzano produkować i emitować w języku polskim liczne audycje radiowe. Powołano w tym celu nawet specjalną redakcję. Ostatecznie już pod koniec października $1939 \mathrm{r}$. zadecydowano, że żadnych programów w języku polskim nie będzie. Zakaz emisji programów miał stanowić element szerszej polityki eksterminacji polskiej kultury, ale co do kształtu programu radiowego nie było jednak jasności. Hans Frank uważał się za suwerena w Generalnej Guberni i dążył do stworzenia własnej, niezależnej radiofonii na tym terenie. Miała ona posiadać swoją centralną siedzibę w Krakowie. Frank podejmował szereg działań w celu zorganizowania tam pełnej infrastruktury produkcyjnej i nadawczej. Na nadawanie niezależnego programu w Generalnej Guberni nie zgadzało się Ministerstwo Propagandy w Berlinie. Dzięki skutecznemu zakazowi importowania obcych gazet i słuchania zagranicznych stacji udało się stworzyć w Rzeszy zamkniętą przestrzeń informacyjną w której można było kreować najbardziej absurdalne wyobrażenia o sytuacji w Rzeszy. Dlatego nieskontrolowane

${ }_{94}$ Zob. S. Fikus, Piękny biust zamiast moralnego kręostupa. Refleksje na temat filmu Reinera Fassbindera „Lili Marleen”, w: Motyw wojny w kulturze i sztuce wizualnej, red. Ł. Jureńczyk, J. Szczutkowska, Bydgoszcz 2017, s. 37-46.

${ }^{95}$ L. Dobroszycki, op. cit., s. 14.

${ }^{96}$ A. Diller, op. cit., s. 410. 
informacje płynące z Krakowa dla tych mistyfikacji mogłyby być zagrożeniem. Ostatecznie wyrażono zgodę na emisję niemieckojęzycznego programu informacyjnego Das Tagesecho des Generalgouvernements w paśmie rozdzielnym programu Rzeszy. Administracja Franka domagała się również wprowadzenia programów informacyjnych w języku polskim. Przełomem okazały się wydarzenia pod Stalingradem. Pod ich wrażeniem wyrażono w Berlinie zgodę na ich emisję. Ostatecznie nadawano codziennie cztery razy audycje w języku polskim na falach średnich i dwukrotnie na falach długich. Frank domagał się co prawda rozszerzenia tej oferty o polskojęzyczne programy publicystyczne i kulturalne, ale na to ustępstwo Kancelaria Rzeszy w Berlinie nie wyraziła już zgody.

\section{Disputes over the Shape of German Broadcasting in Occupied Poland}

German radio policy in the General Government could be divided into several stages. Initially, the intention was to produce and broadcast numerous radio programmes in the Polish language. For this purpose, a special editorial office was established. Finally, at the end of October 1939, it was decided that there would be no broadcasts in Polish. The ban on broadcasting was to be part of a broader policy of extermination of Polish culture. However, there was no clarity about the shape of the radio programme. On the one hand, Hans Frank considered himself a sovereign in the General Government and sought to create his own independent radio station in the area, with its central headquarters in Krakow. Frank took several measures to establish there a complete production and broadcasting infrastructure. The Ministry of Propaganda in Berlin opposed the creation of an independent radio programme in the General Government. Thanks to the effective ban on foreign newspapers and listening to foreign stations, it was possible to form a closed information space where the most absurd ideas about the situation in the Reich could be disseminated. Therefore, uncontrolled information coming from Krakow could have been a threat to these mystifications. Eventually, permission was granted to broadcast the German-language news programme 'Das Tagesecho des Generalgouvernements', aired in the separate band of the Reich's programme. Frank's administration also demanded the introduction of news programmes in Polish. The breakthrough came with the events at Stalingrad. Impressed by them, Berlin agreed to broadcast news in Polish. Eventually, programmes in Polish were aired four times a day on medium wave and twice on long wave. Although Frank demanded this offer be extended to include Polish-language journalistic and cultural programmes, the Reich Chancellery in Berlin did not agree to this concession.

\section{Bibliografia}

Diller A., Rundfunkpolitik im Dritten Reich, München 1980.

Dobroszycki L., Die legale polnische presse im Generalgouvernement 1939-1945, München 1977. Dussel K., Deutsche Rundfunkgeschichte, Konstanz 2010.

Fikus S., Piękny biust zamiast moralnego kręgostupa. Refleksje na temat filmu Reinera Fassbindera „Lili Marleen”, w: Motyw wojny w kulturze i sztuce wizualnej, red. Ł. Jureńczyk, J. Szczutkowska, Bydgoszcz 2017, s. 37-46.

Fikus S., Radiofonia w III Rzeszy. Studium ideowego zniewolenia, Katowice 2018.

Fritsche H.R., Nationalismus und Widerstand im Schlesischen Rundfunk, w: Nationalsozialismus und Widerstand in Schlesien, red. L. Bossle, G. Keil, J. Menzel, E. Schulz, Sigmaringen 1989.

Fritsche H.R., Was am Vorabend des zweiten Weltkrieges in Gleiwitz wirklich geschah, „Fernseh-Informationen” 1979, nr 14-16. 
Kleßmann Ch., Die Selbstbehauptung einer Nation. Nationalsozialistische Kulturpolitik und polnische Widerstandsbewegung im Generalgouvernement 1939-1945, Düsseldorf 1971.

Kwiatkowski M.J., Polskie Radio w konspiracji 1939-1944, Warszawa 1989.

Lachowicz S., Muzyka w okupowanym Krakowie 1939-1945, Kraków 1988.

Schütte W., Rationalität und Föderalismus im Rundfunk. Die Geschichtliche Entwicklung in Deutschland 1923-1945, Frankfurt am Main 1971.

Spiess A., Lichtenstein H., Das Unternehmen Tannenberg, der Anlass zum zweiten Weltkrieg, Wiesbaden 1979.

Wroński T., Kronika okupowanego Krakowa, Kraków 1974.

Sebastian Fikus - dr hab. prof. UŚ; politolog, historyk, publicysta. Pracuje w Instytucie Dziennikarstwa i Komunikacji Medialnej Wydziału Nauk Społecznych Uniwersytetu Ślaskiego w Katowicach. Zainteresowania naukowe: stosunki polsko-niemieckie i historia mediów. E-mail: sebastian.fikus@interia.pl.

Sebastian Fikus - Dr Hab., Professor of the University of Silesia; political scientist, historian, journalist. Employee of the Institute of Journalism and Media Communication at the Faculty of Social Sciences of the University of Silesia in Katowice. Scientific interests: Polish-German relations and history of media. E-mail: sebastian.fikus@interia.pl. 